\title{
FACTS AND FANCIES IN BACONIAN THEORY.
}

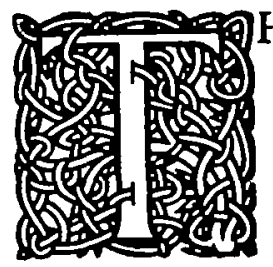

E latest contribution to the perennial conflict of Baconians and Shakespearians comes once more from the pen of Mr. W. H. Mallock. Once again he assumes an attitude of impartial inquiry, and while avowedly detaching himself from the ranks of either side, proceeds to support his case with a long array of ex parte arguments. But he has at least the courage to eschew generalities and condescend to particulars, wherefore it would be no more discourteous than unwise for any who dissent from his conclusions to indulge in mere vague abuse. Moreover, I venture to think that here, no less than in the case of the famous cypher, the advocates of Shakespeare need have no fear of coming to close quarters with their antagonists.

The particular subject of Mr. Mallock's article in the January number of ' The Pall Mall Magazine' is the occurrence of 'emblems' of alleged Baconian significance on the title-pages of certain books of the early seventeenth century. Ornamental title-pages of the sort are, as Mr. Mallock says, of common occurrence, and many most undoubtedly belong to the class of ' emblems.' Now, the subject of 'emblems' is a very large one, and one on which 


\section{FACTS AND FANCIES IN}

a variety of learned works have been written. For such as are unfamiliar with this particular form of ingenuity it may be explained that 'emblems' are pictures of a more or less symbolic intention, generally accompanied by explanatory text, usually in verse, but also sometimes in prose. If for any reason the text is absent, the meaning in most cases becomes quite unfathomable, since, though it is true that a certain amount of conventional symbolism (instances of which are quoted by Mr. Mallock) gives an appearance of 'picture-writing' to the art, it is so restricted as to render little real help to the would-be interpreter. The continuation to 'The New Atlantis,' in which this symbolical language appears most elaborated, was published, it must be remembered, in 1660 , at the very end of the 'emblem' craze, which had by then amused Europe for more than a century and a quarter. The earlier work was in most cases never intended to be selfexplanatory, as anyone may satisfy himself who will turn to such a book as the 'Veridicus Christianus' by the Dutch Jesuit, John David (Plantin, 1601), and endeavour, without referring to the elaborate prose commentary, to make out the meaning of the fine copperplates, even with the assistance of the tri-lingual mottos.

'Emblem' title-pages became the fashion early in the reign of James. They sometimes appear of a simple and obvious kind, as, for instance, that to the 1616 folio of Jonson's works, which bears emblematic figures of the different species of Arama and various classical antiquities, and later that to Bacon's 'Instauratio Magna' of 1620 and Fuller's 'Holy 
War' of 1640 . A far more intricate example, as well as the earliest one that occurs to me at the moment, is that to Raleigh's 'History of the World,' which first appeared in 1614 . This is accompanied by a leaf of explanatory verse, wanting in many copies, headed 'The Minde of the Front.'

These few remarks appear necessary by way of introduction, since Mr. Mallock is inclined to take up the attitude-perhaps excusable in a popular magazine - of introducing his readers to a perfectly new and untrodden field. It may also be premised that Bacon was-teste Baudoin-at least interested in these toys called 'emblems,' just as he was interested in the far more important matter of cyphers. But it does not follow that he was therefore given to introduce the former into other people's titlepages any more than the latter into other people's writings.

Mr. Mallock takes up the position, usual with the defenders of fantastical causes, that his arguments are cumulative. Individually they may not be convincing, but taken together-! We have heard this before. You might as well attack a jelly-fish. He will complacently watch the demolition of support after support of his fairy fabric, the explosion of figment after figment of his scheme, and smilingly murmur 'cumulative evidence!' Not until every single item of his evidence has been proved utterly fictitious will he cease to believe in the alchemy of the words "cumulative evidence" -et encore! But this is a large undertaking!

It is only fair to note that Mr. Mallock claims no originality for the 'facts' and theories he ad-

IV. 
duces; his materials having been supplied from elsewhere. Since, however, he has deemed it fit to make these 'facts' known to the world, and himself the mouthpiece of others, his blood must be upon his own head.

The examples of ' emblem' title-pages dealt with are three in number: those to the 'Spenser' of 1611 , Florio's 'Montaigne' of ${ }^{16} 632$, and Selenus' ' $\mathrm{Cy}-$ phers' of 1624 . We will consider these in order, and I may say here that in every case I have examined the original prints and have not founded any arguments on the facsimiles that illustrate $\mathrm{Mr}$. Mallock's article. Those here given in miniature are intended merely as reminders.

Those acquainted with the bibliography of English literature must be pretty familiar with the ornamental border used in the editions of Spenser of $16 I 1$ and 1617 , but they are also likely to be aware that it was by no means its first appearance. Mr. Mallock hardly seems to grasp the importance of the question as to where it was first used, for he merely informs us in a note, added as by an afterthought, that it is found in the sixth edition of Sidney's 'Arcadia' in 1623 and 'appeared first on the title-page of Bedingfield's translation of Machiavelli's Florentine History.' Now this happens to be incorrect, and the mistake further happens to be of the first consequence, since, as we shall see in a moment, it entirely upsets Mr. Mallock's interpretation of the design. A careful glance at that design itself, with its figures of the shepherd and Amazon, should indeed have made Mr. Mallock suspect its origin-if, that is, he knew aught of 


\section{BACONIAN THEORY.}

Sidney's romance beyond its name. It is quite true that the border appears in the 'Arcadia' of 1623 ; it is also true that it appeared in the editions of that work published in $1593,1598,1613,1629,1633$, and $163_{3} 8$, as well as in the 'Machiavelli' of 1595 and the 'Spenser' of 1611 and 1617 . It is evident that Ponsonby the publisher had the border cut for Sidney's work, and to him the block belonged. The fact of its appearing in the 'Machiavelli' of I 595 (to which it is singularly ill-suited), printed for Ponsonby by T. Creede, suggests that the latter may have been the printer of the 1593 and 1598 'Arcadias.' After this, however, Ponsonby reclaimed the block, for Creede, though he continued in business till 1617 (not 1616 , as usually stated), never, so far as I am aware, used it again, while from 16 I 1 onwards we find it in the hands of the printer Humphrey Lownes, who used it indiscriminately for the works of Sidney and Spenser, and possibly others too. This brief history should suffice to show the danger of attributing significance to the casual appearance of an ornament or pictorial titlepage-border in an old volume.

But now that we know its history let us turn to the design itself and see how Mr. Mallock's remarks accord with the facts. To the figures of the shepherd and Amazon, which Mr. Mallock does not mention, I have already alluded-they obviously represent the two heroes of the romance, Musidorus and Pyrocles, in their disguises of Dorus and Zelmane. The small cut at the top of the page is not a 'hog with a halter' (hog-hanged=Bacon), as Mr. Mallock would have it, but nothing more 
emblematic than Sidney's crest-a porcupine passant azure, quilled, collared and chained or! It is true that it does look rather like a boar-but such is the heraldic porcupine, being furnished with tusks! This crest appears between two beasts, a lion and a bear. Mr. Mallock, of course, at once sees evidence of Bacon's royal descent: 'One belongs to the Queen, the other to the Earl of Leicester.' Here he gets in a right and left and only misses clean with one barrel. The other, however, does but knock out tail-feathers. The bear on the left is undoubtedly that of the Dudleys; but it appears here not because Leicester was the father of Bacon, but because Sidney's mother was the daughter of John Dudley, Duke of Northumberland and Earl of Warwick. The lion on the right, on the other hand (it should have been ducally crowned, just as the bear should have been chained), is the sinister supporter of the Sidney arms. So much for the upper part of the border. At the foot is a picture representing what is this time undoubtedly a hog smelling at a rose-bush, across which runs the motto, 'Non tibi spiro.' Here we have a most undoubted and very typical 'emblem.' This Mr. Mallock interprets as Bacon wistfully regarding the Tudor roses and despairing of having his birth recognized. Those who have followed the explanation of the rest of the border set forth above will perhaps prefer to regard this design as expressing the idea that the delicate perfume of Sidney's courtly fantasy is not meant for the porcine nostrils of the vulgar.

In turning to Montaigne the first difficulty that 


\section{BACONIAN THEORY.}

presents itself is one of chronology. Why was it that the title-page, in which Mr. Mallock finds Baconian emblems, only appeared in the third edition published in 1632 , no less than six years after Bacon's death? This is a difficulty which never seems to have occurred to $\mathrm{Mr}$. Mallock. He plunges straight into the matter of interpretation. The title-page, which has some explanatory verses opposite, is an architectural one, and through an arch in the centre we obtain a view of buildings beyond. Here it becomes necessary to quote Mr. Mallock. 'The two broken arches,' he says, 'are recognizable as inverted F's. In the poem the reader is instructed to look at the title-page with a "glauncing eye," which suggests that he should look at it from different points of view. If, acting on the suggestion, we look at the page sideways, the two arches at the end of the street give us the letter B. We thus get the initials F. B. The buildings beyond the arches are standing in the sea. If we "glaunce" at the plate obliquely, as the strange object at the feet of the figures in Holbein's "Two Ambassadors" is meant to be "glaunced" at (when it foreshortens itself into a human skull), the left-hand arch opens; and the building in the sea, together with the spire, assumes the aspect of a lighthouse, or, as has been suggested, a beacon-a word which was pronounced Bacon, just as the tea of "Great Anna" later on was pronounced tay. ... The circular building [on the left] represents the Globe Theatre, and the [roofless and incomplete] building in front of it the author of the dramas acted there-or, if we 
prefer to say so, the fame or reputation of the author-which is dark and incomplete. On the left-hand side of the great gate is a niche, waiting for a statue, thus repeating the foregoing suggestion that half of Bacon's fame-that of a poet-is hidden : whilst what seems to be a niche opposite to it is not a niche at all, but is an aperture through which a stream of light - the light of philosophy -is admitted. And now let the reader turn to the title which surmounts the gate. $\mathrm{He}$ will see that this, instead of being cut in the stone, and thus forming part of the building, is carefully represented as being written on a movable sheet or banner, affixed to the building by a nail which is not driven home, and suggesting that beneath it is the true title concealed.'

Some readers may, perchance, feel moved to vote all this sheer nonsense without further hearing, but let them have patience, for if we disagree with the interpretation put upon the design by Mr. Mallock, we should at least be able to give our reasons for so doing. Personally I take it that the design is nothing but an ideal picture of the relics of that glorious antique world amid which the meditative genius of Montaigne moved, and I believe that in almost every instance Mr. Mallock has misinterpreted the signs before his eyes in a manner which leaves one little escape from the conclusion that he was blinded by a preconceived theory. As to the initials: even granting that the broken arches have some remote resemblance to F's, why should there be two of them, and why should they be turned the wrong way round? 
('You mustn't leave out so many things,' the White Queen very justly remarked); while it is obviously impossible to draw two arches side by side which will not form a B if looked at sideways. As to 'glauncing'; if Mr. Mallock will consult the 'New English Dictionary' he will find that there is not the least authority for the meaning he here proposes to find in the word; he has moreover, as I shall show in a moment, entirely missed the drift of the explanatory verses in which the word occurs, but which most indubitably do not bid the reader look with ' a glauncing eye.' After a careful examination of the original engraving I furthermore deny that there is the smallest evidence for supposing that the distant buildings are standing in the sea, while looking at the plate from every direction, after the fashion of Holbein's rebus (hohl-Bein), I fail to find any trace of a lighthouse, beacon, or anything of the sort-which, however, may of course be due to my own blindness. With reference to the would-be 'Globe,' it is perhaps sufficient to point out that a round temple roofed has little resemblance with any early theatre, most of which were roofless; least of all with the 'Globe,' which was hexagonal in shape! What Mr. Mallock describes as the unfinished building in front is obviously a ruin, the stones at the top being broken off jagged, and what he calls 'two stone steps, which have evidently not been put in their proper place,' is easily seen in the original to be portions of a fallen frieze. The statueless niche is evidently part of a passage running transversely through the arch, the con- 
tinuation of that through which the light falls on the right. Since the whole picture is lit from this side there is no reason to suppose this particular beam to be the light of philosophy rather than any other beam in this or any other picture. Lastly, I may assure Mr. Mallock that the representing of a title as cut on stone was most uncommon, if indeed it occurs at all, at that date, while the engraving of it on some scroll or compartment as here was very common indeed. It is, therefore, to say the least, gratuitous to suppose that the 'banner' is intended to cover the real title, even were it possible to suppose any more 'real' title than 'The Essayes or Morall, Politike, and Militarie Discourses of Lo: Michael de Montaigne' for the work in question.

But before passing on we must glance at the explanatory verses. They are, it must be confessed, far from perlucid, as is often the case with effusions of this class, but the general drift is sufficiently clear for our purpose. They are too long to quote entire : I will therefore give their drift as it appears to me. "When first this portlike Frontispeece was wrought,' says the poetical exponent, it was the intention of the artist to embellish his design 'With Emblemes, and with Pictures,' drawn from the author's work, in such a manner that the beholder, 'By casting thereupon a glauncing [i.e. casual] eye,' might at once have been informed of the contents of the volume. But, reading through the Essays, that 'Palace ${ }^{1}$ of Invention,' with a view to this, he found such profusion of beauties that ' Misprinted Place in the original. 
merely to enumerate them would need a whole volume. 'For, in those Angles, and among those Leaves,' that is, in every corner of the 'Palace,' and amid the profuse growth of the author's wit, fresh 'Fruits' of genius display themselves everywhere to the carefully inquiring eye, so that they pass far beyond 'a briefe expression,' and he had to abandon his intention. 'In stead of Emblemes therefore,' he has been fain 'To fixe the Authors Title' and name upon his design. The author of the verses then proceeds, in some rather obscure lines, to remark upon the advantage of having the work translated.

Here, then, we have the definite statement that the artist-it was Martin Droeshout, by the bye, who engraved the portrait of Shakespeare in the folio of 1623 : surely Mr. Mallock might have founded some further arguments upon this coincidence-the artist intended to introduce ' emblems' into his design, but, on second thoughts, engraved the title instead. There is, moreover, good reason to suppose that the statement is in accordance with fact, and not merely a versifier's fiction, for a glance either at the original or the facsimile will at once show that certain portions of the architectural design-' Roomes and Galleries,' as the author of the verses calls them-have actually had the frames of such 'Emblemes' and 'Pictures' sketched in upon them. A similar use of architectural panels may be observed alike in the 'Jonson' of 1616 and in Harington's 'Orlando' of 1591 . We are then, I think, justified in assuming that the title-page contains no cryptic 
' emblems,' but that, as I said above, it is merely an imaginary presentment of the ruinated glories of the past.

The third title-page need hardly detain us long. Mr. Mallock appears to attach particular importance to it, since he gives no less than four facsimiles. I do not propose to enter in detail into his interpretations, but only to give what appears to me the obvious significance of the pictures introduced. Beyond the mere fact that the work is on cyphers, and that as we well know Bacon was interested in the subject, as every diplomatist of the time necessarily was, there is, as far as I am aware, no evidence whatever to associate Bacon with the work of Selenus, dedicated to the Emperor Ferdinand II., and published at Luneberg in 1624. A casual perusal has even failed to show that Selenus' monumental work contains Bacon's particular omnia per omnia cypher; but on this point I may be in error. Now, such being the nature of the work, I shall hardly be accused of paradox if I suggest that the pictures, in spite of being distinctly in the style of the 'emblem' artists, are not strict 'emblems' at all, but merely illustrate various incidents in the writing and transmitting of despatches. In the head compartment we see a boat rowing away from a town lit up by beacon fires-possibly escaping with cypher despatches by night from a besieged city. The 'magic circle of the imagination' which, according to Mr. Mallock, incloses this compartment is merely a conventional design to be found repeated ad nauseam in the arabesques of Renaissance ornament ; while of the three 'masks' said to represent 


\section{BACONIAN THEORY.}

tragedy, comedy and farce, two are apparently intended by the anonymous engraver to be identical, differing only in the lighting, and if the third does indeed represent farce, it is certainly the most dolefully tragical farce that ever saddened its beholders. In the left-hand compartment we see a gentleman delivering a paper to a 'foot-man' (i.e., a footmessenger), who is again seen plodding on his way in the middle distance. He carries a spear; but is it necessary to conclude that he must therefore be Shakespeare, even when, as Mr. Mallock admits, there is otherwise not the remotest resemblance? Above is a bird carrying a paper, towards which an arrow is seen flying. This again is easily interpreted as another method of transmitting despatches. On the right again is a messenger on horseback blowing upon a post-horn of the identical shape which may still be seen as the emblem of the postal service in Germany and elsewhere. Lastly, at the foot of the page we see a secretary writing despatches, while a courtier stands by holding a fur cap in his hand. In this last figure Mr. Mallock sees ' a conventional representation of Shakespeare.' As to the probability of this being so, anyone who will look either at the original or facsimile may satisfy himself. It might pass for a clumsy portrait of Raleigh (see the engraving in the later editions of his ' History of the World '), but assuredly not of Shakespeare. The other figure of course is, to Mr. Mallock, Bacon, and he proceeds to announce that his Shakespeare is 'taking a cap of maintenance from his [Bacon's] head.' 'Is it possible,' he further asks, "to explain this picture in any 
other way than as an image of Shakespeare appropriating the philosopher's fame.' Now, although it would seem more probable that the cap belongs in fact to the courtier, it certainly does look in the picture as though he were holding it over the head of the scribe. But whether he is taking it off or putting it on-' that's quite another thing.' Mr. Mallock, it will be observed, calls it a cap of maintenance, but the 'chapeau;' or ' cap of maintenance,' familiar to all students of heraldry, bears not the least resemblance to that here represented-moreover, by no possibility could the cap of maintenance symbolize a poet's fame.

So much for the 'emblems' on which Mr. Mallock relies for his new Baconian ' facts.' But there are one or two incidental points in his article which it is impossible to pass over in silence, since they illustrate with singular clearness the methods of argument to which he is driven to resort. At one point of his discourse it becomes necessary to connect Bacon in some way or other with Florio's translation of Montaigne. Mr. Mallock conveniently finds that one Thomas Powell dedicated a small legal volume called :The Attorney's Academy' to Bacon' as 'Beholden To no Mountaine for Eminence.' I should hardly have myself supposed it necessary to see in this an allusion to Montaigne (or 'Mountaine,' as he is called in the explanatory verses to the 1632 'Essays'), nor that

1 It was published, says Mr. Mallock, 'four years after Bacon's death,' but he seems in no wise disturbed at this. The fact is, of course, that the edition of 1630 is a reprint, the work having originally appeared in 1623 . 
even so it followed that there was any connection between the two authors beyond the fact of their both having written essays. But this is not all. Mr. Mallock's quotation from the dedication is garbled. The original runs, in the quarto of 1623 , "To True Nobilitie and Tryde Learning, Beholden To no Mountaine for Eminence, nor Supportment for his Height, Francis, Lord Verulam, and Viscount $\mathrm{s}^{t}$. Albanes.' By the omission of the parallel clause, Mr. Mallock is guilty of a suppressio veri, which, as is almost always inevitable, is at the same time a suggestio falsi.

One point more, and I have done. This time it is concerned with the alleged royal birth of Bacon, in support of which Mr. Mallock quotes some doggerel hexameters giving the sovereigns of England, which are inscribed on the wall of Canonbury Manor at Islington, where Bacon once lived. He quotes:

'HENRICUS

OCTAVUS, POST HUNC EDW: SEXT, REGINA MARIA

ELIZABETHA SOROR : SUCCEDIT FR ... JACOBUS.'

Then he adds, 'With the exception of the first two letters, the word beginning with FR has been obliterated. What can this mutilated word stand for, unless it stands for Francis ?' Now in the first place the list goes on to mention Charles. It was therefore cut after the death of James, and so in all probability after that of Bacon, when it can have been nobody's interest to perpetrate any such in- 
discretion. Secondly, supposing that we do read ' Franciscus' for the mutilated word, it gives no possible sense, since, whatever his rights may have been, Bacon certainly never occupied nor laid claim to the English throne. Thirdly, there is not the remotest reason for reading ' Franciscus.' The poetaster, as I take it, pressed alike for metre and for a Latin equivalent for ' cousin,' wrote 'frater' - 'frater patruelis' is the full term, but the omission of the adjective is perfectly classical. Then some criticaster coming along remarked that James was not Elizabeth's brother and obliterated the word. The compiler of the verses in any case only scanned according to accent, but of the two my emendation violates classical rule the least.

Admirers of Mr. Mallock may possibly be inclined to regard his article as very pretty fooling, but it is nevertheless something disheartening to find it necessary to waste time pointing out wild misstatements of fact and exploding equally wild interpretations when the nature of both alike must have become apparent to Mr. Mallock had he condescended to examine the evidence for himself before rushing thus intrepidly into print.

$$
\text { Walter W. GReg. }
$$

Postscript.-In a further article, just received, three more title-pages are discussed, but the interpretations put forward are again utterly impossible, and this quite apart from the contentions they are made to support. Did space allow, it would not, I believe, be difficult to interpret the 'emblems' in a much more natural manner. Mr. Mallock is apain repeatedly wrong on points of fact, but I have probably already said enough to show approximately how far his statements are to be trusted. 